\title{
Expression of SP and ALP Following the Application of Watermelon Frost in Reversible Pulpitis: An In Vivo Study
}

\author{
Dennis Dennis ${ }^{1}$, Trimurni Abidin², Narlan Sumawinata ${ }^{3}$
}

\begin{abstract}
Aim: The aim of this study was to examine the effect of watermelon frost (WF) on the expression of substance P (SP) and alkaline phosphatase $(A L P)$ in reversible pulpitis.

Materials and methods: A total of 32 teeth of Macaca fascicularis (M. fascicularis), which were given mechanical injury until the pulp was exposed, were included in the study. Group I (without WF): 16 teeth were included in group I in which the pulp tissues were extracted and stored at $-80^{\circ} \mathrm{C}$ until tested by enzyme-linked immunosorbent assay (ELISA). Group II (with WF): 16 teeth were included in which WF was applied and teeth extraction was performed after 3 days and pulp tissues were obtained by breaking the tooth. Pulp tissues were stored at $-80^{\circ} \mathrm{C}$ until tested by ELISA. Independent sample $t$ test was used to analyze the difference between the study groups.

Results: The mean and standard deviation (SD) values of SP were $159.085 \pm 7.104$ in group I and $44.852 \pm 3.708$ in group II. The mean and SD values of ALP were $38.076 \pm 2.991$ in group I and $144.805 \pm 10.959$ in group II. A significant difference in the SP and ALP concentrations was observed in group I as compared to group II $(p<0.05)$.

Conclusion: The results concluded that WF has an effect on the increasing expression of ALP and decreasing SP expression in reversible pulpitis. Clinical significance: Watermelon frost is effective for the treatment of reversible pulpitis.

Keywords: Alkaline phosphatase, Macaca fascicularis, Reversible pulpitis, Substance P, Watermelon frost.

World Journal of Dentistry (2020): 10.5005/jp-journals-10015-1717
\end{abstract}

\section{INTRODUCTION}

Pulp inflammation or pulpitis is one of the most commonly encountered oral problems in dental practice. Pulpitis can be of two types, namely, reversible and irreversible pulpitis. ${ }^{1}$ In case of reversible pulpitis, the pain is relieved after removal of the stimulus or irritant and the tooth is restored. Clinically, irreversible pulpitis leads to spontaneous pain and the pain is felt even after the stimulus is removed because the pulp tissue is located in an area of low compliance and poor collateral circulation. The management of irreversible pulpitis includes the removal of the pulp and disinfection and root canal filling followed by restoration of the tooth. ${ }^{2}$

Pain is one of the cardinal signs of inflammation, including both reversible and irreversible pulpitis. The painful process, according to the Field et al., occurs during several stages, ${ }^{3}$ namely, transduction, transmission, modulation, and perception. Substance $\mathrm{P}$ (SP) is a neuropeptide generated by sensory A-delta and C fibers. ${ }^{4-6}$ In addition to being a vasodilator, SP also induces interleukin 8 , which is a cytokine that is strongly chemotaxic against neutrophils. ${ }^{7}$ The SP also plays an active role in neurogenic inflammation. ${ }^{8}$ Tuncer et al. suggested that the expression of SP is increased in inflamed tissue. ${ }^{9}$ Associated with prostaglandin $\mathrm{E}_{2}\left(\mathrm{PGE}_{2}\right)$, which sensitizes nociceptors, $\mathrm{SP}$ also reportedly induces the expression of cyclooxygenase 2 (COX 2), an enzyme that mediates the formation PGE ${ }_{2}{ }^{10}$ Therefore, suppression of SP expression is important to relieve pain. ${ }^{10}$

Various substances have been used to treat tooth pain (pulpitis), for example, eugenol, pulperyl, and others. ${ }^{2}$ The World Health Organization has advocated the use of natural ingredients in addressing a variety of diseases including dental pain. ${ }^{11}$

Watermelon frost has long been used in the traditional Chinese medical community to treat inflammation in the oral cavity, tooth pain, swollen gums, burns, etc. ${ }^{12}$ Watermelon frost (WF) is obtained from watermelon (Citrullus vulgaris), and it is processed using

\begin{abstract}
1,2Department of Conservative Dentistry, Faculty of Dentistry, Universitas Sumatera Utara, Padang Bulan, Medan, Indonesia

${ }^{3}$ Department of Conservative Dentistry, Faculty of Dentistry, Universitas Indonesia, Jakarta, Indonesia

Corresponding Author: Dennis Dennis, Department of Conservative Dentistry, Faculty of Dentistry, Universitas Sumatera Utara, Padang Bulan, Medan, Indonesia, Phone: +62 8126555068, e-mail: dennis@ usu.ac.id

How to cite this article: Dennis D, Abidin T, Sumawinata N. Expression of SP and ALP Following the Application of Watermelon Frost in Reversible Pulpitis: An In Vivo Study. World J Dent 2020;11(2):151-155.

Source of support: Nil

Conflict of interest: None
\end{abstract}

Glauber's salt (sodium sulfate decahydrate). Watermelon frost may reduce the levels of $\mathrm{PGE}_{2}$ in teeth with acute irreversible pulpitis. Watermelon frost reportedly also has antibacterial properties against Streptococcus mutans. ${ }^{13}$

Watermelon frost was reported to have therapeutic effect against body heat and it can reduce the level of inflammation and infection. In addition, WF has efficacy to promote healing and repair. ${ }^{12,13}$

The effect of watermelon frost on the expression of SP has not been investigated. Healing is part of the inflammatory tissue reaction. One aspect of healing is the formation of hard tissues, which is known as dentinogenesis. This happens by the formation of reactionary dentin (indirect pulp capping) or reparative dentin (direct pulp capping). ${ }^{2}$ Reactionary dentin is formed by the activity of the surviving odontoblasts, while reparative dentin formed as normal cell activity of odontoblast. ${ }^{10}$ One of the markers of the occurrence of remineralization is the increased levels of alkaline 
phosphatase (ALP). ${ }^{14}$ An extensive search revealed no literature regarding the effect of WF on ALP activity.

As there is no data on the effect of WF on the expression of SP and ALP, the aim of this study was to determine the effect of WF on the expression of SP and ALP in teeth with reversible pulpitis in Macaca fascicularis.

\section{Materials and Methods}

\section{Preparation of WF}

The trial material in this study was WF obtained from a red watermelon fruit (C. vulgaris) weighing $2.5-3 \mathrm{~kg}$. The watermelon fruit was obtained from the Universitas Sumatera Utara plantation. The watermelon was cut into two pieces and a hole was made on one side of the watermelon. The hole was then filled with $500 \mathrm{~g}$ of Glauber's salt $\left(\mathrm{Na}_{2} \mathrm{SO}_{4} \cdot 10 \mathrm{H}_{2} \mathrm{O}\right)$. After that it was covered with the other side of the watermelon and then it was placed in a refrigerator at $4^{\circ} \mathrm{C}$ for 7 days until the time of "frosting". White powder appeared on the outer rind of the watermelon.

\section{Experimental Animal}

This study used $M$. fascicularis teeth as samples because their teeth structure and the dental pulp are similar to humans. The experimental procedure was performed in accordance with the Animal Research: Reporting of in vivo Experiments guidelines. In this experiment, 32 teeth were obtained from two adult male longtailed macaques ( $M$. fascicularis) aged 6 years and weighing $4 \mathrm{~kg}$. The long-tailed macaques were obtained from Primate Research Center, Institute Pertanian Bogor with ethical approval ACUC No. IPB PRC-14-B002 and Health Research Ethical Committee of North Sumatera, Medical School Universitas Sumatera Utara (No. 145/ KOMET/FK USU/2014). Each subject was treated under general anesthesia with propofol at a dose of $2-4 \mathrm{mg} / \mathrm{kg}$ body weight by intravenous (IV) bolus, and $0.2-0.4 \mathrm{mg} / \mathrm{kg} / \mathrm{hour}$ with a syringe pump. The entire procedure was done by certified veterinarian.

\section{Experimental Procedure}

The pulp tissues of all teeth (incisors, canines, premolars, and molars) were considered and the excavation did not depend on the number or weight of the pulp because it was expected to heal and repair/regenerate. The whole endodontic treatment procedure was performed by the author who is a board-certified endodontist. Teeth with mechanically induced reversible pulpitis were included in the study. Drilling on the roof of the pulp was performed under sedation using a combination of ketamine 10-15 mg/kg and/or xylazine $0.5 \mathrm{mg} / \mathrm{kg}$ or diazepam $1 \mathrm{mg} / \mathrm{kg}$ intramuscularly and IV. Drilling with no. 2 access bur was performed to expose the pulp.

In group I, a pulpotomy was performed immediately in 16 teeth to extract the pulp tissue. Excavation of the pulp tissue was done using a sterile excavator. In group II (16 teeth), the area of pulp exposure had WF applied and then the tooth was restored with resin-modified glass ionomer cement.

Acetaminophen was given orally at a dose of $5-10 \mathrm{mg} / \mathrm{kg}$ as an analgesic to reduce the distress after treatment. After 3 days, euthanasia was performed by injecting sodium pentobarbital at a dose of $200 \mathrm{mg} / \mathrm{kg}$ IV under anesthesia and the teeth were extracted for excavation and analysis of the treated pulp tissue.

\section{Dental Pulp Tissue Extraction Procedure}

Weighed pulp tissue samples were homogenized in 15\% methanol in 0.1 sodium phosphate buffer saline solution at $\mathrm{pH} 7.5(100 \mathrm{mg}$ in $1 \mathrm{~mL}$ of methanol buffer). Then the samples were centrifuged for 5 minutes at $2400 \mathrm{rpm}$ and the supernatant was transferred into a new tube. The supernatant was preconditioned with C18 Sep-Pak column (Waters Corporation) by washing the column with $2 \mathrm{~mL}$ of methanol followed by $2 \mathrm{~mL}$ of water. The supernatant was then put into the tooth pulp column and the flow rate was adjusted to $1 \mathrm{~mL}$ / minute. The samples were diluted in phosphate buffer saline (PBS) 1:3 or 1:6 (10-100 mM, pH 7.0) to increase the flow rate. The column was then washed with $2 \mathrm{~mL}$ of $15 \%$ methanol in water followed by petroleum ether. Elution extraction was performed using $2 \mathrm{~mL}$ of methyl formate. The methyl formate eluate was evaporated with nitrogen gas flow. The residue was dissolved in approximately $1 \mathrm{~mL}$ when the expected sample concentration was low $(<0.1 \mathrm{ng} / \mathrm{mL})$.

\section{Procedure of Enzyme-linked Immunosorbent Assay}

The extracted pulp tissue was placed in Eppendorf containing $0.5 \mathrm{~mL}$ of PBS at pH 7.5 and centrifugation was done at $2400 \mathrm{rpm}$ for 5 minutes in order to obtain the supernatant; after that, it was restored at temperature $-80^{\circ} \mathrm{C}$. The quantitative level of SP and ALP was seen by using Enzyme-linked Immunosorbent Assay (ELISA) using "ELISA reader" that showed the absorbance level of color at the wavelength $450 \mathrm{~nm}$ and corrected wavelength $570 \mathrm{~nm}$. Quantitative analysis of SP and ALP levels was done using ELISA in both the study groups.

\section{Statistical Analysis}

All data were tabulated and entered into a Microsoft Excel data sheet. Statistical analysis was done using Statistical Package for Social Sciences (SPSS Inc. v. 17.0, Chicago, IL, USA). Means and standard deviations of the concentration of SP and ALP were computed. The Kolmogorov-Smirnov normality test was used to check the normality of the data. The data were found normally distributed. The independent sample $t$ test was then used to test the difference between the two groups. Statistical significance was considered at $p$ value of less than 0.05 .

\section{Results}

The means and SD values of SP were $159.085 \pm 7.104$ in group I and $44.852 \pm 3.708$ in group II (Table 1). The mean and SD values of ALP were $38.076 \pm 2.991$ in group I and $144.805 \pm 10.959$ in group II (Table 2). A significant difference in the SP and ALP concentrations was observed in group I as compared to group II ( $p<0.05)$.

Table 1 shows the comparison of the concentrations of SP (pg/ $\mathrm{mL}$ ) for the groups with and without administration of WF. The concentration of SP in the group with WF was less than one third that of the group without WF. The $t$ test results showed that this difference was highly significant $(t=52.491, p<0.05)$.

Table 1: Comparison of the concentration of substance $P(\mathrm{pg} / \mathrm{mL})$ in reversible pulpitis with and without administration of WF

\begin{tabular}{llllllll}
\hline Group & Mean & SD & Min & Max & Mean diff & t value & $p$ value \\
\hline Without WF & 159.085 & 7.104 & 151.569 & 175.138 & 114.232 & 52.491 & $0.000^{*}$ \\
With WF & 44.852 & 3.708 & 37.217 & 52.501 & & & \\
\hline
\end{tabular}

*Significance is considered at $p<0.05$

WF, watermelon frost 
Expression of SP and ALP Following Application of WF in Reversible Pulpitis

Table 2: Comparison of the concentration of alkaline phosphatase $(\mathrm{ng} / \mathrm{mL})$ in reversible pulpitis with and without administration of WF

\begin{tabular}{lccccccc}
\hline Wjoud_ & Mean & SD & Min & Max & Mean diff & $t$ value & $p$ value \\
\hline Without WF & 38.076 & 2.991 & 34.599 & 47.392 & -106.729 & -36.600 & $0.000^{*}$ \\
With WF & 144.805 & 10.959 & 133.9 & 167.988 & & & \\
\hline
\end{tabular}

*Significance is considered at $p<0.05$

WF, watermelon frost

Table 2 shows the comparison of the concentrations of ALP $(\mathrm{ng} / \mathrm{mL})$ for the groups with and without administration of WF. The concentration of ALP in the group with WF was about four times that of the group without WF. The $t$ test results showed that this difference was highly significant $(t=-36.600, p<0.05)$.

\section{Discussion}

This study was conducted to examine the effect of WF on the expression of SP and ALP in teeth with reversible pulpitis in $M$. fascicularis. Watermelon frost has anti-inflammatory effects that are seen with the decrease in the concentration of $\mathrm{PGE}_{2}$. It also has antibacterial properties against S. mutans. ${ }^{13}$

The role of SP in the inflammatory process has been studied by Payan. ${ }^{15}$ Both in vitro and in vivo tests have shown the role of SP in increasing the cellular response and stimulating monocyte chemotaxis. The results of this study also show a large increase in the levels of SP with the commencement of neurogenic inflammation and nociception in teeth with reversible pulpitis. The results are consistent with previous studies. ${ }^{7,16}$ Keiser and Byrne stated that SP interacts with mast cells that release histamine, and it also causes increased blood pressure and pulp vascular permeability. ${ }^{2}$

Previous research conducted by Caviedes-Bucheli et al. not only reported an increase in the level of SP in inflamed pulps, but they also looked at normal pulps. ${ }^{17}$ In the normal pulp, the SP serves to maintain the balance of vascularity in order to maintain blood flow to the pulp and nutrient supply consistently as well as regulating pressure in the interstitial pulp, which is in a noncompliant network environment. ${ }^{18}$ In this study, it showed that the concentrations of SP decreased significantly after application of WF. Therefore, it can be deduced that the experimental group experienced a reduction in inflammation and hence maintained good vascularity. Also, a significant decrease in SP means a state of balance and homeostasis that will spur the repair and healing process of the pulp. ${ }^{19}$ Applying WF when there was reversible pulpitis due to mechanical injury in this study led to a decrease in the level of SP, so that there was a reduced inflammatory condition in the environment in the area of injury homeostasis, triggering cell proliferation and recruitment of progenitor cells and tissue remodeling. ${ }^{20}$

This study demonstrated potent anti-inflammatory effects of WF against SP. The reduction in concentration of SP in the present study was likely to be due to a number of compounds in watermelon that can reduce tissue inflammation. Some of the known compounds are citrulline and flavonoid compounds that have potent anti-inflammatory effects. ${ }^{20}$ This is also consistent with the previous studies that showed that WF could be used to prevent and reduce influenza. ${ }^{15}$ It was also used in the treatment of inflammatory conditions of the pharynx and larynx. ${ }^{21}$ Similar results were observed in a study done by $\mathrm{Naz}$ et al. ${ }^{22} \mathrm{~A}$ study by Wu et al. also demonstrated that WF has therapeutic effects, which were used to treat pharyngitis, laryngitis, and sore teeth. ${ }^{23}$ All of these reports highlight that watermelon has anti-inflammatory and antioxidant properties that can be used for the prevention and treatment of many diseases. Watermelon is used for treating various ailments in the Ayurvedic system of Indian medicine. It belongs to the family of Cucurbitaceae and is the most commonly consumed fruit worldwide, also known as an energy booster, due to its rich content of nutrients, vitamins, and minerals. ${ }^{24}$

The decline in the group given SP WF is also consistent with the research done by Johnson et al., ${ }^{11}$ which showed that watermelon has a number of compounds that have anti-inflammatory and antioxidant effects that can be used for disease prevention and treatment. Killough et al. suggests that WF has long been used by the Chinese community in treating inflammation and infection of the teeth and oral cavity. ${ }^{16}$

Recent studies reported that the $C$. lanatus seeds contain a high level of antioxidant compounds such as arginine and linoleic acids, as major fatty acids. These act as potent antioxidant and antimicrobial agents which are essential for promoting angiogenesis in wounds. ${ }^{24}$

The increase in ALP concentrations seen 3 days after applying WF is consistent with the beginning of the healing process in injured pulps since ALP is an early marker of the commencement of the mineralization process. ${ }^{21,25}$ These results are consistent with the research conducted by Yu et al. and Yu et al. who found that the concentration of ALP increases in pulps undergoing healing. ${ }^{26,27}$

Increased ALP is likely caused by antioxidant and antiinflammatory compounds, i.e., a number of important minerals and vitamins in watermelon (Citrullus vulgaris) which led to the acceleration of pulp healing. ${ }^{22}$ Watermelon contains citrulline frost and various organic and inorganic compounds which have a therapeutic effect. ${ }^{20}$ This observation is also supported by Morotoni et al. who reported that odontoblast-like cells were stimulated so that the pulp can differentiate heat stress. ${ }^{28}$ The extent of the injury will not affect the calcification activity of cells that are thermoresistant, but this capability is more influenced by nutritional factors. ${ }^{28}$ Magne et al. also suggested that the process of reparative dentinogenesis will occur due to injury that can damage the cells of the pulp. ${ }^{29}$

Research conducted by Semeghini et al. also found an increased concentration of ALP in rats that had undergone reparative dentinogenesis by pulp cells that do not differentiate. ${ }^{30}$ Arana-Chavez and Massa suggested that odontoblasts have the defense capabilities to heal and ALP is one of the earliest markers of healing. ${ }^{31}$ In this study, after application of WF for 3 days, increased concentrations of ALP were seen which suggests that the WF stimulated the mineralization process. The ALP plays an important role in the initiation phase of the mineralized tissues. In the transition phase of odontoblast cell lineage, ALP has been used as a marker that was expressed during the process of cell differentiation to odontoblasts. ${ }^{15}$

The mineral content in WF can act as a conductor for the regeneration of pulp tissue by beginning the differentiation and proliferation of stem cells to form odontoblasts. ${ }^{30,31}$ 
The components of WF show great potential in expressing ALP because of the availability of nutrients needed for healing and repairing the pulp and also the availability of water required for the diffusion of the ions. ${ }^{30-32}$

When a decrease in inflammation and increase in pulp tissue repair and dentinogenesis occur, a sequence of molecular changes occur through a process of making the interdependence of each gene expression. ${ }^{30-32}$ The present study showed that the application of WF led to a significant decrease in SP concentration and an increase in ALP concentration. The decrease in SP in the inflamed pulp means that the pulp can reach a state of homeostasis through blood flow regulation, so the pulp then has the ability to heal and initiate dentinogenesis that was evident by the expression of ALP. ${ }^{30-32}$ The reduced concentration of SP also has implications for the reduction in neurogenic inflammation, the modulation of the function of immunocompetent cells, and the regulation of growth of endothelial cells. ${ }^{30-32}$ It also plays an important role in the process of nociceptive neurotransmission input, so the pulp can return to its normal physiological state and reactivate the entire defense system. ${ }^{32}$ The present study was in accordance with the findings of Pashikanti et al. that watermelon has antioxidative stress and antineurodegenerative effect..$^{33}$ It shows a positive correlation between the nervous system and the immune defense mechanisms as well as the pulp. ${ }^{30-33}$

\section{Conclusion}

Watermelon frost can be used to reduce pulp inflammation as indicated by a decrease in the concentration of SP. It can also be used for dentin remineralization as indicated by the increasing concentration of ALP.

\section{Clinical Significance}

Watermelon frost can be used as a treatment alternative for tooth with reversible pulpitis.

\section{Acknowledgments}

The authors would like to thank Primate Research Center/Pusat Studi Satwa Primata (PSSP), Institute Pertanian Bogor (IPB) for the help provided in this study.

\section{Availability of Data and Materials}

The data analyzed during this present study are available from corresponding author on reasonable request.

\section{Authors' Contributions}

Dennis Dennis, Trimurni Abidin, and Narlan Sumawinata conceived the original idea and designed the experiment. Dennis Dennis performed the experiment, collected, and analyzed data. Dennis Dennis, Trimurni Abidin, and Narlan Sumawinata contributed to the interpretation of the results. Dennis Dennis wrote the manuscript with support from Trimurni Abidin and Narlan Sumawinata. All authors read and approved the final manuscript.

\section{Ethics Approval and Consent to PARTICIPATE}

This study was approved by Animal Care and Use Committee Primate Research Center-Institute Pertanian Bogor (ACUC No. IPB
PRC-14-B002) and Health Research Ethical Committee of North Sumatera, Medical School Universitas Sumatera Utara (No. 145/ KOMET/FK USU/2014).

\section{Consent to Publish}

The authors have given the consent for publication.

\section{References}

1. Iqbal M, Kim S, Yoon F. An investigation into differential diagnosis of pulp and periapical pain: a PennEndo database study. J Endod 2007;33(5):548-551. DOI: 10.1016/j.joen.2007.01.006.

2. Keiser K, Byrne BE. Endodontic pharmacology. In: Hargreaves KM, Cohen S. Pathways of the Pulp. 10th ed., St. Louis, USA: Mosby Elsevier; 2012. pp. 671-690.

3. Field JW, Gutmann JL, Solomon ES, et al. A clinical radiographic retrospective assessment of the success rate of single-visit root canal treatment. Int Endod J 2004;37(1):70-82. DOI: 10.1111/j.13652591.2004.00765.x.

4. Sattari M, Mozayeni MA, Matloob A, et al. Substance P and CGRP expression in dental pulps with irreversible pulpitis. Aust Endod J 2010;36(2):59-63. DOI: 10.1111/j.1747-4477.2009.00186.x.

5. Caviedes-Bucheli J, Muñoz HR, Azuero-Holguín MM, et al. Neuropeptides in dental pulp: the silent protagonists. J Endod 2008;34(7):773-788. DOI: 10.1016/j.joen.2008.03.010.

6. Henry MA, Hargreaves KM. Peripheral mechanisms of odontogenic pain. Dent Clin NAm 2007;51(1):19-44.DOI: 10.1016/j.cden.2006.09.007.

7. Tokuda M, Miyamoto R, Nagaoka $S$, et al. Substance $P$ enhances expression of lipopolysaccharide-induced inflammatory factors in dental pulp cells.J Endod 2004;30(11):770-774. DOI: 10.1097/00004770200411000-00005.

8. Sacerdote P, Levrini L. Peripheral mechanisms of dental pain: the role of substance P. Mediat Inflam 2012. 1-7. DOI: 10.1155/2012/ 951920.

9. Tuncer LI, Alaçam T, Oral B. Substance P expression is elevated in inflamed human periradicular tissue. J Endod 2004;30(5):329-332. DOI: 10.1097/00004770-200405000-00006.

10. Rodd HD, Boissonade FM. Substance P expression in human tooth pulp in relation to caries and pain experience. Eur J Oral Sci 2000;108(6):467-474. DOI: 10.1034/j.1600-0722.2000.00924.x.

11. Johnson JT, Iwang EU, Hemen JT, et al. Evaluation of antinutrient contents of watermelon Citrullus lanatus. annals. Biol Res 2012;3(11):5145-5150.

12. Zhang Y. Comprehensive methods for preventing and treating influenza. J Chinese Med 2001;65:6-10.

13. Dennis $D$, Trimurni A. The effect of watermelon frost on prostaglandin $\mathrm{E}_{2}\left(\mathrm{PGE}_{2}\right)$ in inflamed pulp tissue (in vitro study). Dent J 2009;42:82-85.

14. Golub EE, Boesze-Battaglia K. The role of alkaline phosphatase in mineralization. Curr Opin Orthop 2007;18:444-448. DOI: 10.1097/ BCO.0b013e3282630851.

15. Payan DG. Neuropeptides and inflammation: the role of substance P. Ann Rev Med 1989;40:341-352. DOI: 10.1146/annurev. me.40.020189.002013.

16. Killough SA, Lundy FT, Irwin CR. Substance P expression by human dental pulp fibroblasts: a potential role in neurogenic inflammation. J Endod 2009;35(1):73-77. DOI: 10.1016/j.joen.2008.10.010.

17. Caviedes-Bucheli J, Camargo-Beltrán C, Gómez-la-Rotta AM, et al. Expression of calcitonin gene-related peptide (CGRP) in irreversible acute pulpitis. J Endod 2004;30(4):201-204. DOI: 10.1097/00004770200404000-00004.

18. Awawdeh L, Lundy FT, Shaw C, et al. Quantitative analysis of substance $P$, neurokinin $A$ and calcitonin gene-related peptide in pulp tissue from painful and healthy human teeth. Int Endod J 2002;35(1):30-36. DOI: 10.1046/j.1365-2591.2002.00451.x

19. Caviedes-Bucheli J, Gutierrez-Guerra JE, Salazar F, et al. Substance P receptor expression in healthy and inflamed human pulp tissue. Int Endod J 2007;40(2):106-111. DOI: 10.1111/j.1365-2591.2006.01189.x. 
20. Inuwa HM, Aina VO, Gabi B, et al. Determination of differences in nutrient composition of Citrullus vulgaries (watermelon) fruits after plucking. Brit J Dai Sci 2011;2:27-30.

21. Zou J, Lu H, Pan Z. Clinical study of watermelon frost runhou tablet treatment for pharynx and larynx oral cavity. Lin Chuang Er Bi Yan Hou Ke Za Zhi 2003;17(4):253-255.

22. Naz A, Butt MS, Pasha I, et al. Antioxidant indices of watermelon juice and lycopene extract. Pakistan J Nutrit 2013;12:255. DOI: 10.3923/ pjn.2013.255.260.

23. Wu J, Jin F, Tang $\mathrm{L}$, et al. Dentin non-collagenous proteins (dNCPs) can stimulate dental follicle cells to differentiate into cementoblast lineages. Biol Cell 2008;100(5):291-302. DOI: 10.1042/BC20070092.

24. Iswariya S, Uma TS. Evaluation of in vitro anti-inflammatory and antimicrobial activity of aqueous and methanolic seed extracts of Citrullus lanatus. Int J Pharm Pharm Sci 2017;9(5):29-33. DOI: 10.22159/ ijpps.2017v9i5.16708.

25. Lopez-Cazaux S, Bluteau G, Magne D, et al. Culture medium modulates the behaviour of human dental pulp-derived cells: technical note. Eur Cells Mater 2006;11:35-42. DOI: 10.22203/eCM. v011a05.

26. Yu J, Wang Y, Deng Z, et al. Odontogenic capability: bone marrow stromal stem cells vs. dental pulp stem cells. Biol Cell 2007;99(8): 465-474. DOI: 10.1042/BC20070013.
27. Yu J, Deng Z, Shi J, et al. Differentiation of dental pulp stem cells into regular-shaped dentin-pulp complex induced by tooth germ cell conditioned medium. Tiss Engin 2006;12(11):3097-3105. DOI: 10.1089/ ten.2006.12.3097.

28. Morotomi T, Kitamura C, Toyono T, et al. Effects of heat stress and starvation on clonal odontoblast-like cells. J Endod 2011;37(7): 955-961. DOI: 10.1016/j.joen.2011.03.037.

29. Magne D, Bluteau G, Lopez-Cazaux S, et al. Development of an odontoblast in vitro model to study dentin mineralization. Connect Tiss Res 2004;45(2):101-108. DOI: 10.1080/03008200490464839.

30. Semeghini MS, Fernandes RR, Chimello DT, et al. In vitro evaluation of the odontogenic potential of mouse undifferentiated pulp cells. Braz Dent J 2012;23(4):328-336. DOI: 10.1590/S0103-64402012000400004.

31. Arana-Chavez VE, Massa LF. Odontoblasts: the cells forming and maintaining dentine. Int J Biochem Cell Biol 2004;36(8):1367-1373. DOI: 10.1016/j.biocel.2004.01.006.

32. Yu C, Abbott PV. An overview of the dental pulp: its functions and responses to injury. Aus Endod J 2007;52(1 Suppl):S4-S6. DOI: 10.1111/j.1834-7819.2007.tb00525.x.

33. Pashikanti G, Ajitha M, Puchchakayala G. Neuroprotective effect of Citrullus lanatus seed extracts on cerebral ischemic reperfusion injury induced cognitive impairment and oxidative stress. Int J Pharm Pharm Sci 2019;11(6):38-44. DOI: 10.22159/ijpps.2019v11i6.32963. 